\title{
Modern Bireyin Tereddütleri: "Çıplaklık" Düșüncesi ve "Bir Tereddüdün Romanı"
}

\section{Emel ARAS 1}

\begin{abstract}
ÖZ
Modern birey, yaşadığı yüzyılların doğası gereği teknolojik olarak ilerleme kaydedildiği ölçüde sıkı̧̧mışlık duygusu ile yüz yüze gelir. Bu duygu fiziksel veya psikolojik olarak bazı marazlara neden olabileceği gibi farklı düşünme biçimleriyle de kendini ortaya koyabilir. Bireyin merkezî unsur haline geldiği modern toplum yapısı, bu durumların açığa çıkış biçimlerini de çeşitlendirmiştir. Bu noktada "çıplaklık" düşüncesi de kendini gösterebilir. Peyami Safánın "Bir Tereddüdün Romanı” adlı eserinde öne çıkarılan bu düşünce birçok farklı anlam alanına açılmaktadır. Bu çalışmada, "giyinme" düşüncesiyle birlikte ortaya çıkaan "çıplaklık" kavramı diyalektik bir bakış açısıyla değerlendirilmesi ve bu doğrultuda modern bireyin var oluş sancılarının bir boyutuyla ele alınması amaçlanmıştır. Bu bağlamda, "çıplaklık” düşüncesinin hem metaforik hem de gerçek anlamı üzerinde durularak modern bireyin yaşamında kapladığı alan tartış1lmış, "çıplaklık" düşüncesinin açtığı anlam alanları doğrultusunda modern insanın yaşamdaki konumlanı̧̧ı üzerinden değerlendirilmiştir.

Çalışmanın ana teması özelinde, özellikle eserin iki ana karakteri olan Vildan ve Muharrir karakterleri etrafında oluşturulan ana gövde üzerinden bu iki karakterin birbirleriyle ve diğer karakterlerle kurdukları ilişkinin temaya olan katkısı üzerinde durulmuştur. Söz konusu ilişkiler ağının, özellikle, Vildan ve Muharrir'in benzer bakış açılarına sahip olmaları nedeniyle giderek daralan bir yapıya sahip olduğu görülmüş, toplumsallıktan bireyselliğge doğru ilerleyen helezonik bir görüntü ortaya çıkmıştır. Bu görüntünün çokkatmanlı yapısının arkasında modern bireyin kendini var etme gayretlerinin etkilendiği unsurların bulunduğu düşünülebilir. Zira, modern çağ ile birlikte insanoğlu birçok etkenin etkisi altına girmiş ve kendini var etme yolculuğunda öncelikle bu etkenlerden kurtulma çabasını göstermek zorunda kalmıştır. Vil-
\end{abstract}

Araştırma Görevlisi, Düzce Üniversitesi Türk Dili ve Edebiyatı Bölümü, Yeni Türk Edebiyatı Anabilim Dalı, Düzce/TÜRKIYE.

E-posta: emelaras@duzce.edu.tr, ORCID: 0000-0002-1221-5012,DOI: 10.32704/erdem.572815

Makale Gönderim Tarihi: 26.10.2018 * Makale Kabul Tarihi: 27.03.2019 * (S. ve Edebiyat Mk.) 
dan ve Muharrir karakterlerinin bu etkenlerden kurtularak kendi özlerine yönelik birtakım arayışlar içine girdiği tespit edilmiştir. Öyle ki çağrışımsal yükü oldukça fazla olan "çıplaklık" düşüncesi etrafında felsefi anlamı yüksek bir diyaloglar silsilesi açığa çıkmıştır. İnsanın özüne dönüşü ile özdeşleştirebileceğimiz "çılaklık" düşüncesi, kendinden uzaklaşan insana yönelik bir uyarı niteliğindedir.

Bu çalı̧şada da amaçlanan söz konusu iki karakter özelinde "çıplaklık" ve "giyinme" düşüncelerinin altında yatan felsefi derinliği, modernite sonrası düşünceler ve düşünürler 1şı̆̆ında tartı̧mak ve öne atılan argümanları mümkün olduğunca bir yere oturtma gayesi taşımaktadır.

Anahtar Kelimeler: Çıplaklık, giyinme, modern birey, Peyami Safa, Bir Tereddüdün Romanı. 


\section{ABSTRACT \\ The Hesitations of Moden Person: The Thought of "Nakedness" and "A Novel of the Hesitation"}

Modern person faces to the feeling of being stuck by the nature of the centuries which he/she lives. This feeling can either cause physical or psycological diseases or reveals itself as different way of thinking forms. The modern society structure which man becomes at the center element diversifies the emerging forms of this situations. At this point, the thought of "nakedness" can reveal itself. This thought, which put forward by Peyami Safa's "A Novel of the Hesitation", opens different meaning fields. In this study, the concept of "nakedness" which emerges with the thought of "dressing" will be examined in a dialectical point of view and we aim to deal with the existence of pain of modern human in an extent. At this context, by laying emphasis on the real and metaphoric meaning of the thought of "nakedness", the field of this concept in the life of modern person will be discussed, through the meaning fields of "nakedness", it will be evaluated on the basis of the position of modern person in the life.

Specially for the main theme of the study, through the main corpus which creating around the main characters of the novel, Vildan and Muharrir, laid emphasis on the contribution of the relationships of this two and others on the theme. It is seen that the relation network becomes gradually narrow, cause of the similarity of Vildan and Muharrir's point of views, emerges a spiral image which proceeds from community to individuality. It can be thought that behind this image's multilayer structure, there are elements which modern person's efforts of realization himself. Because, with modern era human being fall under the influence of many factors and he is primarily obliged to get over these factors through the realization trip of him. It is determined that the characters of Vildan and Muharrir evaded from these factors and in search of something about their selves. Therefore, some dialogues which have high philosophical values can reveal themselves. The thought of "nakedness", which has a high evacatory value, can be assimilated with the return of human to himself is like an alert of human who departs of him.

The aim of this study is to discuss the philosophical depth of which lay behind the thought of "nakedness" and "dressing" through in the light of thoughts of after modernity and it's thinkers, especially on the two characters and there is also an another aim is to settle the arguments, which are executed, on a ground.

Keywords: Nakedness, dressing, modern person, Peyami Safa, A Novel of the Hesitation. 


\section{Modern Toplum, Modern İnsan, Modern Sanat}

O n dokuzuncu yüzyılda yaşanan düşünsel ve teknik ilerlemenin bir sonucu olarak insan varlığ da kendi dönüşümünü yaşamış ve "modern insan” 1 var etmiştir. Yaşadığı sosyal çevre dolayısıyla dönüşen insanın sanat anlayışı da aynı itici unsurlar tarafından ortaya çıkmıştır. Descartes'ın "düşünüyorum, o halde varım” sözleriyle kendini var eden kartezyen öznenin açtığı bireysellik yolunda toplumun ve sanatın merkezine insan yerleşir. İnsa$\mathrm{n} ı$ merkeze alan ve onun çıkarlarını gözetecek bir toplum yaratma ideali, zamanla insansızlaşan ve iktidar odaklarının gücü doğrultusunda hareket eden bir yapıya evrilir. Her ne kadar modern dönem ve modernist sanat arasında zıtlıktan beslenen bir ilişki olsa da modernleşmenin sonunda ortaya çıkan bu kavramlar, yaşanan anlam karmaşasının bir sonucu olarak düşünülebilir.

Modernist düşünce insana hak ettiği değeri vereceği iddiasıyla ortaya çıkar ve Ortaçağ’’n karanlığına bir güneş gibi doğarken, insana "birey" olma vaadini sunar. Bu vaat, Rönesansla birlikte herkese sunulan eşit bir hak gibi ortaya çıkmasına rağmen, zamanla seçkinci bir yaklaşıma dönüşür. Habermas'ın "tamamlanmamı̧̧ bir proje" olarak nitelendirdiği modernite, Rönesans'ın büyük vaatlerle ortaya koyduğu nesnel aklın yerini, Horkheimer'in tabiriyle, "araçsal akla" bırakmasıyla birlikte insanın dünya üzerindeki varlığına ilişkin son derece derin sorgulamalara giriştiği bir dönemi başlatır. Herkesin tektipleştirilerek, "ilerleme" ülküsüyle aynı hedefe doğru yöneltilmesi, Ortaçağ’da derebeyleri ve kilise aracılığıyla alenen kurulan iktidar sisteminin biçim değiştirerek yeniden var oluşuna neden olur. "Aydınlanma sayesinde özgürleştirilen insanlar sonunda, doğadaki her şeyi yinelenebilir kılan soyutlamanin ve bu soyutlamanın hazırladiğı endüstrinin düzleştirip eşitleyen egemenliği altında, Hegel'in Aydınlanmanın bir sonucu olarak nitelendirdiği "düzenli birlikler" [Trupp] haline geldiler" (Adorno,Horkheimer, 2014, 31). "Düzenli birlikler" haline getirilen bireylerin, kendi var oluşlarının anlamı üzerine düşünmeye başlaması ile modernite projesi çöküş sürecine girer. Bireylerin öz benliklerine yönelik giriştikleri aydınlama çabası zamanla kendi problemlerini açığa çıkarır. Bu bağlamda, Charles Taylor modernliğin üç sıkıntısından bahseder. Buna göre ilk kaygı nedeni bireyciliktir, ikincisi, dünyanın büyüsünün çözülmesinin verdiği tedirginlik, üçüncüsü ise bireycilik ve araçsal akıl nedeniyle özgürlüklerin daralmasıdır. (Taylor, 2017, 10-16). Bu üç sıkıntının yarattığ1 kaygı ortamı, çalışmanın ana eksenini oluşturan "Bir Tereddüdün Romanı" adlı eserde de kendini var eder. Eserdeki tartışmalara sahne olan ve sıklıkla göndermede bulunulan "Çıplakları Giydirmek" adlı piyes modernist bir oyun yazarı olan Luigi Pirandello'ya aittir. Modern sanatın bir temsilcisi olarak eserde kendini var eden yazar, kendi bakış açısını ortaya koyduğu "Pirandel- 
list" eserlerinde diğer modernist yazarlar gibi, kendi yazım sürecinde etkili olan unsurlara dikkat çeker ve oyunlarının teatral yönüne odaklanır:

\begin{abstract}
"Modern sanatçılar, yazarlar ve besteciler, genellikle çalı̧̧makta oldukları medya ya da malzemelere, kendi sanatlarnndaki yaratma süreçlerine dikkati çekerler. (...) oyun yazarları oyunlarının teatral yorumlarını bilinçli olarak açı̆̆a vururlar (örn. Mayerhold, Pirandello, Brecht). Böylelikle modernistler, sanatı "dı̧ssal" gerçeklik olduğu iddia edilen şeyin sadece saydam bir "yansiması" ya da "sunulmasi" baline getirmek için yeni bilimsel iddiaları veri olarak alan eskimiş girişsimlerden kaçarlar." (Lunn 2011:55).
\end{abstract}

Pirandello'nun kendi eserlerini oluştururken takındığ 1 bu tutum, Safáya da yansır. "Bir Tereddüdün Romanı" adlı eserde, Pirandello'nun "Çıplakları Giydirmek" adlı oyunuyla açık bir metinler arası ilişki kuran Peyami Safa da eserinin merkezine Muharrir karakterini koyarak, Eugène Lunn'un "Modernist eser kendi gerçekliğini bilinçli olarak bir yorum ya da oyun olarak açığa vurur" (Lunn 2011: 55, 56) ifadeleriyle örtüşen bir tavır sergiler. Eserde Muharrir karakterinin yaşadığı psikolojik buhranları metinleştirmesi de böylesi bir duruma işaret etmektedir. Daha özele inersek, karakterlere yaklaşım noktasında da benzer bir modernist tavrın benimsendiği görülür. Karakterin derinlik kazandığı modernist yazın, eserde söz edilen durumun ya da eylemin edimcisi olması anlamında karaktere özel bir önem atfeder:

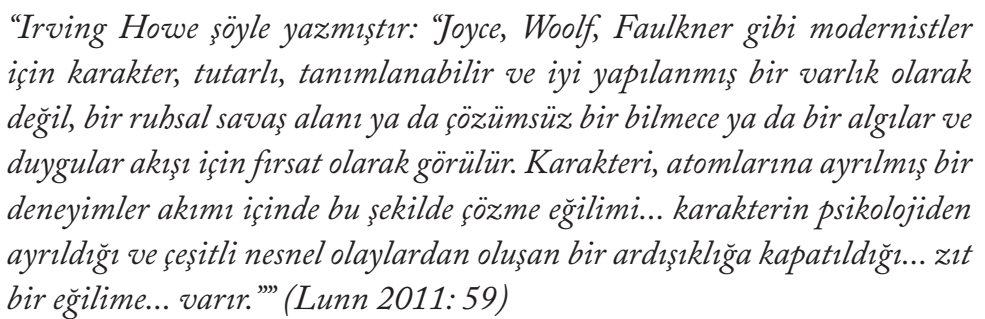

Modern yaşamın insanı tek boyutlu, sıradan bir yapı olarak düşünerek "herkesleştirmesi” modern yazının ise insanın ruhsal yönüne de eğilerek ona derinlik katması bağlamında açığa çıkan modernlik ve estetik modernizm ikiliğinin giderek keskinleştiği görülmektedir. Söz konusu ikilem aynı itici unsurların var ettiği iki zıt durum yaratması açısından önem arz etmektedir.

"Kesin olan şey on dokuzuncu yüzynlın belli bir noktasında, Batı uygarlğının taribindeki bir aşama olan modernlik -bilimsel ve teknolojik ilerlemenin, Sanayi Devriminin, kapitalizmin yol açtığı o her şeyi alip götüren ekonomik ve toplumsal değişimlerin bir ürünü olan modernlik-ve estetik 
bir kavram olan modernlik arasında geri döndürülemez bir yarılmanın meydana geldiği." (Calinescu 2017: 47).

$\mathrm{Bu}$ nedenle, estetik modernizm ile birlikte karakter, romanın anlam katmanlarını arttırması noktasında yapı taşı haline gelmiştir. Özellikle, topluma yabancılaşma bağlamında ortaya çıkan çokkatmanlı yapı, Calinescu'nun "Modern yazarın yabancılaşma tarihi romantik hareketle başlar" (Calinescu, 2017: 49) ifadelerinde de görüldüğü üzere, başlangıç noktasını romantizme dek götürür.

\section{Giriş}

Yaşam ve roman ilişkisi birçok yazar için kaçınılmaz bir birliktelik anlamını taşır. Çoğunlukla roman yazarı kendi hayatından aldığı kesitleri romanının bir yerlerinde kimi zaman bilinçli kimi zamansa bilinçsizce kullanır. Türk Edebiyatı'nın önemli isimlerinden olan Peyami Safa da birçok eserine kendi yaşamından parçalar aksettirmiş, romanlarını kendi duygu ve zihin dünyasının sahnesi haline getirmiştir. "Bir Tereddüdün Romanı" adlı eserin de böylesi bir sahne niteliği taşıdığı söylenebilir. Safa da bu bağlamda, modernleşme sancıları çeken bir toplumun içerisiden kendi içine doğru yükselen bir ses olarak nitelendirilebilir.

1899 yılında dünyaya gelen Peyami Safa, altmış iki yıllık yaşamı boyunca Birinci ve İkinci Dünya Savaşları, Osmanlı İmparatorluğu'nun yıkılışı, Türkiye Cumhuriyeti'nin kuruluşu ve sonrasında yaşanan Batılılaşma sancılarının yakın bir şahidi olmuştur. Bu zaman dilimi, Virginia Woolf'un "Bay Bennett ve Bayan Brown" adlı makalesinde "insan doğası 1910 yılının aralık ayında ya da o sıralar değişti” (Woolf, 1924: 4) diyerek modernleşmenin başladığını kastettiği yılları da içine alan dünya çapında derin bir buhranın yaşandığı yıllardan oluşur. Dünyaya yön veren dengelerin değişmesiyle dünya çapında yaşanan bu krizin elbette modern Türk aydınları üzerinde de etkisi olmuştur. Bu etkiyi Peyami Safáda da görmek mümkündür. Safa, kendi yaşam deneyimlerini eserlerine aktarırken içinde bulunduğu koşulları kendi zihin aynasından yansıtarak değerlendirir. İnci Enginün Safa'nın bu yaklaşımını şu sözlerle değerlendirir:"İlk roman Sözde Kizlar (1922)'dan itibaren toplumun çeşitli yaralarm deşen, insan psikolojisini derinlemesine tablile girişen Peyami Safa, I. ve II. Dünya savaşlarının getirdiği yeni şartların toplumun yerleşik değerlerini nasıl alt üst ettiğini ele alır" (Enginün, 2017: 294). Bu yaklaşım, Safa'nın kendi bulunduğu konumdan dünyayı anlamlandırma gayesinde olduğuna işaret eder. Yazar, kendi düşüncelerini paylaşırken, karşı düşüncelerle 
zıtlık ilişkisi kurar ve kahramanlarını da bu doğrultuda şekillendirir. Temelde doğru ve yanlış belirlemesi üzerinden hareket eden yazar, çatı̧̧mayı geniş bir alana yayar. "Gatışma bütün mekânlar ve herkes arasındadır. Hiçbiri olmazsa kişiler kendi içlerinde bölünmüşlüğü yaşarlar. Duyuş tarzı bakımından son derece huzursuz bir modern dönem kişisi olan yazar, kendi dünya görüşünü de kabramanlarına yansıtmıștır" (Enginün, 2017: 296).

\section{Bulgular ve Yorum}

Eser; Muharrir, Raif, Mualla ve Vildan karakterleri etrafında inşa edilmiş ve özellikle Muharrir'in Vildan ile kurduğu ilişki bağlamında ortaya çıkan düşünceler öne çıkarılmıştır. Bu düşüncelerden bir tanesi de İtalyan yazar Luigi Pirandello'nun "Çıplakları Giydirmek" adlı oyunundan yola çıkılarak ortaya koyulan "çıplaklık" düşüncesidir. Peyami Safa ile birlikte düşünebileceğimiz Muharrir'in Vildan ile kurduğu ilişki özelinde öne çıkarılan bu düşünce, savaş sonrası psikolojisi ve modernleşme düşüncesinin bir sonucu olarak değerlendirilebilir. Evrensel anlamda ilerleme düşüncesinin iki büyük dünya savaş1 ile yarattığ 1 yıkım ortamının neden olduğu kaotik durum, Peyami Safa'nın eserinde de dikkat çekilen bir durumdur. Vildan karakterinin temsil ettiği "hiçbir şeye / hiçbir yere ait olamayan" insan prototipinin var oluş nedeni de modernizmin insana değer verme noktasında vaat ettiklerini gerçekleştirememiş olmasıdır.

Modernleşme ile ortaya çıkan "düzen" düşüncesi, belirli güçlerin gölgesi altında var olan insan kalabalıklarının ortaya çıkmasına neden olmuştur. Zamanla "devlet" adı altında bir kurumla resmiyet kazanan bu durum, insanların tek tipleştirilerek, çeşitliliğin yol edilmesine neden olmuştur. Buna göre, düzen esasıyla ortaya çıkan "devlet" düşüncesi, kendi çıkarları doğrultusunda oluşturduğu sistem içerisinde sessizce var olmaya boyun eğen, kurallardan sapmayan ve bu kuralları doğa kanunu addeden insan tipinin oluşmasını ve varllğıını sürdürmesini sağlanmıştır. Eserde yer alan "çıplaklık" düşüncesi de böylesi bir düzenin karşısında yer alma noktasında atılan ilk adımın metaforik olarak dile getirilişine işaret ettiği düşünülebilir. "Çıplakları Giydirmek" adlı eserden yola çıkılarak üzerinde durulan "çıplaklık" ve "giyinme" ikilemi modern dünyanın temel gerilim unsurlarındandır. Eserin "Tanrı anlatıcısı" da bu gerilimin farkındadır. Çıplaklığı, "kaos"la, giyinmeyi ise "düzen” düşüncesi ile özdeşleştirecek olursak, dünyaya mal olan iki büyük savaşın ilkinin sonunda anlatıcı, kendi tarafını "giyinme" düşüncesinden yana seçer. Bununla kast edilen "düzen"den yana olmak, düzenin içinde toplumsal kuralların izin verdiği ölçülerle yaşamayı kabul etmektir. Çünkü anlatıcı, 1918'den sonra ortaya çıkan yıkım atmosferi ve sonrasında varolan parçalanmış, aykırı, anarşik 
sistemleri ve yaklaşımları reddeder. Dolayısıyla Vildan karakteriyle somutlaştırılan ve modern dünyanın tüm sıkıntılarını kendi bünyesinde taşıyan insanların birer birer yok olacağına işaret eder.

\begin{abstract}
“O halde nereye gidiyoruz? Tereddüt. İnsanlik 1918'den sonraki kadar hiçbir zaman tereddüt etmemiştir, bu mubakkak; fakat muharrir de büyük bir harbin sarsıntısın yıkılıs zanneden imansızlardandır. Hayır. Büyük Harpten sonra bütün dünya bir ağaç gibi silkelenmeğe başladı. Bu sarsıntıya mukavemet edemeyen müstehase kıymetler, birer çürük yemiş gibi sapır sapır dökülecekler; anarşiye istinat eden bütün aykır yeni sanat şekilleri ve anarşi içinde kalan bütün zekâlar da beraber gidecek. İste bir tanesi de şu, su önümde yatan, uykusunda bile rub ibtilâlleri geçiren ve sıçrayan kadın." (Safa 2016: 192).
\end{abstract}

“Tanrı anlatıcı"nın bir ibret nesnesi olarak sunduğu Vildan karakteri, olmaması gereken/kötü olan durumundadır. Dolayısıyla, modernleşme düşüncesinin altında yatan çok yönlülük durumunun zamanla iki zıt kutba indirgenmesi hali, eserde de Vildan ve anlatıcı arasındaki zıtlık üzerinden okunabilir. $\mathrm{Bu}$ zıtllk durumu, beden ve akıl ikiliği üzerinden de düşünülebilir. Vildan, insanın bedensel, coşkun yönüne işaret ederken, anlatıcı akılsal olandan yanadır. Simgesel düzeyde Apollon-Dionysos ikiliğine işaret eden bu durum, gerçek anlamda erkek-kadın diyalektiğini imler. Modernliğin kadını ve kadınsal olanı öteleyerek erkeğe has olanı yüceltmesi fikri bu eserde de Vildan karakteri özelinde, bir "yanlış modernleşme” biçimi olarak açığa çıkar.

"Modernliğimizin dram, bizzat kendisini oluşturan iki yarıdan biriyle mücadele ederek, yani bilim adına özneyi kovarak, Descartes döneminde ve bir sonraki yüzyılda hâlâ yaşayan Hıristiyanlığın katkısını reddederek, akıl ve ulus adına, Hiristiyanlıktaki ve doğal bukuk kuramlarındaki (Atlas Okyanusu'nun her iki kıyısında da insan ve yurttaş hakları beyannamelerini doğurmuş olan) ikiciliğin mirasını yıkarak gelişmis olmasında yatar. Öyle ki, aslında modernliğin temel bir bölümünün yıkılışı hâlâ modernlik olarak adlandırılmaktadır. Modernlik ancak özneyle aklın, bilinçle bilimin etkileşimiyle mevcutken, bize, bilimi yüceltmek için özne fikrinden vazgeçmenin, akl özgür kılmak için duygu ve imgelemi susturmanın, tutkularla tanımlanan toplumsal kategorileri, yani kadınları, çocukları, emekçiler ve sömürgeleştirilmiş olanları, akılculıkla özdeşleştirilen kapitalist bir seçkinler grubunun boyunduruğu altına sokmanın gerektiği fikri dayatıldı" (Touraine, 2016: 264). 
İnsanın ruhsal ve bedensel yönünü iki ayrı alan olarak değerlendirilen bu düşünce biçimi, en sonunda modernliğin kendi çizdiği sınırlar çerçevesinde bize tek tip insan telkininde bulunur. Vildan gibi "çıplaklık" düşüncesine yakın olan şahsiyetler, çoğunluk karşısında varlıklarını sürdürememeye mahkumdurlar. Anlatıcı, bir yandan "çıplaklık" düşüncesinin anlam alanları üzerine Vildan üzerinden değerlendirmelerde bulunurken, bir yandan da Vildan ve ona ait düşüncelerin yanlışlı̆̆ına işaret eder. Dolayısıyla bir yanda iyiler/ahlaklılar yer alırken diğer yanda kötüler/ahlaksızlar yer alır.

Çıplaklık düşüncesinin ele alınması konusu; Muharrir'in, Pirandello’nun "Çıplakları Giydirmek" eserini çevirmesi ile hikâyeye dâhil olur. Muharrir ve Vildan'ın görüşmesi esnasında ikili arasında geçen diyalogda, Vildan, oyunun ana karakterlerinden Erzilya ile özdeşleştirilirken, Muharrir ile oyundaki Romancı karakteri arasında koşutluk kurulur.

"Chıplakları Giydirmek" Bu isim hossuma gidiyor. İtalyancasın bilmiyorum, fakat Türkşesi Fransizcasindan bin kat daba güzel; gramer tasarrufu, icaz ve ahenk olarak güzel: Chiplaklar Giydirmek... Siz nasıl tercüme ettiniz bunu?

- Çıplakları Giydirmek.

- Ne iyi. Sizi tanıdiğım andan bu ana kadar her noktada beraber gidiyoruz.

Ciplakları Giydirmek... Neydi o kadının ismi?

-Erzilya.

-Erzilya.

-İste o, benim. Romancı da sizsiniz." (Safa 2016: 110).

Vildan ve Muharrir eser üzerine konuşmayı sürdürürken piyesten parçalar okurlar ve "çıplakları giydirmek" metaforunun altında yatan anlam üzerine düşünürler. Özellikle bu diyalog, anlatıcının "çıplaklık" ve "giyinme” metaforları üzerine düşündüğünü ve okuru da düşündürmek istediğine işaret eder. Karakterler, Pirandello'nun "Çıplakları Giydirmek" sözlerinin taşıyabileceği anlamsal yük üzerine düşünürken, "söylem üzerine söylem”de bulunarak anlam alanlarını açmaya çalışırlar. Bu anlamsal arayışın taşıdığ felsefi altyapı özellikle Muharrir'in, "Oscar Wilde'ın estetiğini severim” demesinin ardından verilen cevapta görülebilir: 
"Evet, Pirandello'nun çıplakları giydirmekten anladı̆̆ı da bu değil mi? Hepimiz, Erzilya gibi, güzelleşmek için yalan elbiseleri arıyoruz ve çılak hakikati örtmeğe, gizlemeğe çalışıyoruz; hatta kefen bile çıplak cesedimizin çirkinliğini gizlemek için beyaz bir yalandır, değil mi? Sonra, derler ki, cins kediler bu çirkinliği gizlemek için tenha yerlerde ölmeğge giderlermiş. Bazı hayvanların estetiği de bizimkinin aynı." (Safa 2016:114).

Estetik anlamda çirkinliği örtmekle, çıplaklığı giydirmeyi özdeşleştiren Vildan, ölüm düşüncesinin de çirkin bir düşünce olduğu ve tüm ölümlülerin onu bir şekilde kapatma/örtme arzusu taşıdıklarına vurgu yapar. Bu bağlamda, insanın öz varlı̆̆ının çirkin bulunması düşüncesi de modernizmin insanlığa armağanları arasındadır. Bedenin hor görülmesi/aşağılanması, insanın kendi bedeninden uzaklaşarak ondan tiksinmesi, "giyinme"nin caiz olduğu modern dünyanın en tabii yaklaşımlarındandır. Zira modern dünyanın metayı merkezî unsur haline getirişi, insan bedeninin de metalaşmasına neden olur. Bedenin kendi öz varlığıyla aşağılık bir nesne haline getirilmesi, onun biçim değiştirmesini ve dolayısıyla "giyinme"sini zorunlu kılar. İnsanı bu gibi düşüncelere sevk eden ve bu anlamda eylemde bulunan özne devlet/iktidardır. İktidarın kendi gücünü var etme ve sürdürebilme amaciyla hareket etmesi Foucault'nun da işaret ettiği gibi insan bedeninin biricikliğinden uzaklaşması amacını taşır. Foucault, beden ve iktidar ilişkisi bağlamında kendisine yöneltilen "Farklı kurumlar düzeyinde bedensel bir fantasma söz konusu mudur?" sorusuna şöyle yanıt verir: "Sanıyorum ki en büyük fantasma, istençlerin evrenselliğiyle olușturulan toplumsal bir beden fikridir. Oysa, toplumsal bedeni ortaya çıkaran şey konsensüs değildir, bizzat bireylerin bedenleri üzerindeki iktidarın maddiliğidir" (Foucault, 2015, 39). İnsanların bedenleri üzerindeki iktidarın maddiliği, bedensel bir ortaklık yaratarak, onlara bir yön verme gayesi taşır. $\mathrm{Bu}$ yönlendirme hali temel bir egemenlik arzusunun sonucudur. Tektipleştirme ile insanların dikkatleri farklı yönlere çekilerek düşünme becerileri köreltilir, böylece iktidarın kontrolü altında "sahte cennet"ler kurulmasına imkân tanınmış olur.

Vildan'ın hiçbir şeye/hiçbir yere ait olamayı̧sı, Muharrir ile görüşmesi esnasında sürekli birilerine görünmekten çekinmesi, hep bir kaçış hâli içerisinde olması da "modern" bir birey olduğuna işaret eder. Marshall Berman'ın Marx'a göndermede bulunarak ortaya koyduğu "katı olan her şey buharlaşıyor”(Berman, 2013: 58) ifadeleriyle koşut olarak Vildan, her şeyin yıkıldığını ifade eder. Bu yıkım hâli de üzerinde yükseldiğimiz zeminin kayganlığ̣ ile ilgili bir durumdur. Güven problemi, yalnızlaşma, yabancılaşma ve eserin temel itici unsuru olan tereddüt düşüncesi aynı kaynaktan türeyen, 
modernleşmenin neden olduğu duygu durumlarıdır: "Bu gürültüler arasında Vildan'in bağırarak ve daha ziyade kıymet vererek telaffuz ettiği bazı kelimeler, cümleler kulağıma çalınıyordu; "Gıplakları Giydirmek!" - "Hiç değilse şu kadarcık, anladın mı, şu kadarcık!" - "Tereddüt!” - "Yıkılıyor, her şey yıkilıyor!” sonra Lâtince misralar" (Safa 2016:168).

Vildan, yaşamı boyunca birçok şeyi deneyimlemiş fakat tamamlanamamış/ eksik kalmış bir kadındır. Bu durum da dolaylı olarak, bir şekilde metaforik olarak "giyinmeye" çalıştıkça "çıplak" kalmaya mahkûm olmuş bir insan tipinin ortaya koyulmasıyla sonuçlanır. Bu insan tipi, bir nevi modern insanın prototipi olarak düşünülebilir: her şeye meyilli ama hiçbir şeye ait değil.

\begin{abstract}
"Sen hayatında her şey yapmı̧ bir kadınsın. Fakat hiçbirine alı̧̧amamı̧̧sın, hiçbirinde ihtisas kazanamamısssın: Eviendin, fakat tam mânâsıyla zevce olmadın; sevdin, fakat yekpare bir aşkın olmadr, birçok hâdiseler en büyük ibtirasin billûrunu kırdi; seyahat ettin, fakat sende bir seyyah melekesi teşekkül etmedi; birçok hafiflikler yaptın, barlarda, balolarda, tiyatroların kulis aralarında yaşadin, fakat bir kokot pişkinliği elde edemedin; tercümeler yaptın, fakat bir satır yazı neşretmedin; çocuklara bayıllyorsun, fakat ana olmadın; her emelin, her gayennin büyüklüğ̈̈n̈̈ ve güzelliğini anlyorsun, fakat biçbir emelin ve gayen yok; bir çocuk saflğıyla en basit yalanlara inanabilirsin, fakat biçbir șeye iman etmiyorsun" (Safa 2016: 130).
\end{abstract}

Vildan ve Muharrir arasındaki diyaloglarda birkaç kez "yıkılıyor, her şey yıkılıyor!" nidaları öne çıkar. Bu haykırış da modern dünyanın tüm kazanımlarının Birinci Dünya Savaşı'yla yok olduğuna, güvensizlik ve dolayısıyla tereddüt duygusunun açı̆̆a çıkmasına neden olur:

-Dinle beni. Demin bir cümlen hoșuma gitti. Belki farkında olmadan bütün bir devri o cümle ile izah etmiş oluyorsun: "Yıkıllyor, her şey yıkılıyor!'” (Safa 2016: 168).

Modernizmin insan bedenine olan olumsuz yaklaşımı ve maddenin öne ç1karılmasıyla kurulan yeni dünya düzeninde doğadan uzaklaşmanın temel alınması nedeniyle yaşanan madde ve beden ikilemine eserde de dikkat çekilmiştir. Nietzsche'nin Apollon-Dionysos ikiliğiyle dikkat çektiği akıl/ruh ve beden zıtlı̆̆1, modernitenin aklı yüceltilen bedeni ise hor görülen bir nesne durumuna indirgemesine yönelik bir tespitler bütünüdür. Nietzsche, "Bir zamanlar ruh aşağılayarak bakıyordu bedene: ve o zamanlar bu aşağglama yücelerin yücesiydi: - bedenin zayıf, iğrenç, açlıktan ölmek üzere olmasını isterdi ruh. Böylece bedenden ve yeryüzünden kurtulabileceğini düşünürdü."(Nietzsche, 2017, 7) ifadeleri, Safa'nın "çıplaklığı giderme" düşüncesiyle yakından ilişkilidir. $\mathrm{Ru}$ - 
hun bedeni aşağılayarak ondan özgürleşmek istemesi, vahşi olandan medeni olana doğru yaşanan dönüşümün temel güdüsüdür. Safa, tırnakların kesilmesi ve cilalanması ile olduğundan farklı görünme arzusunun yansıtıldığına işaret ederek, insanın çirkinliklerini, dolayısıyla vahşi ve doğal tarafını gizleme ihtiyacını somutlaştırır: "Tırnaklarımızı ya kesiyoruz yahut cilâlı maddelerle parlatıyor ve güzelleştirmeğe çalışıyoruz, yani tırnağımızın çıplakliğın gideriyoruz. Pirandelli bundan babsetmiyor; hâlbuki manikür, en çirkin tarafimızla mücadelemizdir ve ellerimizde gizlenen vâhş̧ pençeye insanî bir şekil vermek içindir" (Safa 2016: 177).

Vildan ve Muharrir'in ruh halleri parçalanmaya/ öze dönüşe meyillidir. Bu durum, ellerindeki kadehleri parçalamaları ile eyleme dökülür. Bu hareketle birlikte kadehi oluşturan cam kırıklarına dönme arzusu da açı̆̆a çıkar. Cam kırıkları, "çıplaklık”la özdeştir ve maddenin kendini oluşturan “öz”̈̈ne yaklaşılırken, insan bedeninin giydirilmesine duyulan isteğe yapılan örtük bir gönderme olarak değerlendirilebilir: "Gene arka üstü uzandık. Fakat ellerimizde boş kalan kadehler bizi rahatsiz ediyordu. İkimiz de bir anda ve birbirimize biç haber vermiş olmadan, kadebleri odanın ortasına firlatıp attık, parçaladık ve sustuk" (Safa 2016: 178).

İnsanın yaşam durumundan ölüme geçişi de giyinme ve çıplaklık durumları arasındaki diyalektik ilişkinin bir benzerini yansıtır. Canlı varlığıyla kendini dönüştürebilen insan doğasının ölümle birlikte içine düştüğü statik durum tam manasıyla bir çıplaklık halidir. Vildan'ın ölüm arzusunu tek başına kaybolarak gerçekleştireceğini ve ölüsünü dahi kimsenin görmeyeceğini dile getirmesi çıplaklık isteğinin yalnızlık duygusuyla kurduğu özdeşliğe işaret eder.

\footnotetext{
"Tek başıma tek, tek... Saçlarımın arasına rüzgârları doldurarak, üstünde elbisemi paralayacağım. Göğsümü güneşlere ve gecelere açarak, haykırarak ve türkü söyleyerek, ağlayarak ve kabkahalar atarak gideceğim. Ve kaybolacağım, ölüme giden kediler gibi kaybolacağım, şılak öleceğim, fakat beni kimse görmeyecek. Bak, Erzilya gibi söylüyorum: Şayet evlenirsen ona de ki, çılak öldü, fakat kimseye göstermedi ve şimdi iskeleti hiçbir insanın göremeyeceği bir ăgacın kütüğ̈̈ne dayalıdır" (Safa 2016: 184).
}

Anlatıcıya göre, Birinci Dünya Savaşı sonrası bir "çıplaklık" durumu meydana gelmiş ve komünizm, kapitalizm gibi insan mantı̆̆ının mahsulü olan tüm sistemler çökmüştür. Bunun neticesinde de insanlığın tek istikameti "tereddüt" haline gelmiştir. (bkz. Safa, 2016: 192). Bu satırların yer aldı̆̆1 son bölüm yazar-anlatıcının kendi düşüncelerini dile getirdiği bir bölüm halini almış ve modernleşen dünyanın marazları birer birer sıralanmıştır. 
İnsanın yalnızlığını gidermek adına bir başkasıyla yahut bir nesneyle bağl1lık kurması da modern dünyada mümkün gözükmemektedir. Zira, "bağl1lık" düşüncesi beraberinde uzun soluklu sadakat odaklı ilişkileri de getirir. Fakat, modern dünyada birçok seçenek aynı anda sunulur ve insanlar her şeyi olduğu gibi ilişkileri de hızlı bir biçimde tüketme eğilimindedirler.

“-Aman ne güzel... Senin yanında her şey güzel... Evet, kendimi daima öldürebilirim.

- Benim yanımda böyle şeylerden bahsetme.

- Dinle, dinle... Ben hiçbir şeye bağlı değilim, sana bağlanabilir miyim? Güvenebilir miyim? Cevap ver!

- Hayır. Hiç kimseye güvenme.

-Ah, bari yalan söyle.

-Cıplakları giydirelim, değil mi? Hayır! Doğruyu söyleyeceğim. Güvenme bana, güvenme. Sana bir vazife fikriyle bağlanamam. Hislerime gelince, onlara güvenilmez. Fakat dikkat et ki, gene en güvenilecek insan, bunu söyleyebilendir. Buna rağmen güvenme.” (Safa 2016: 126).

Bu satırlarla birlikte insanın iç yüzüne yönelen yazar, kendi benliğini bir kenarda tutarak, dış dünya ile arasına mesafe koyar. Bunu yaparken takındığg1 dürüst tavır "çıplaklık" durumunun tezahür etme biçimlerinden biri olarak düşünülebilir.

"Çıplaklık" düşüncesini anlamlandırma noktasında ciddi bir çaba sarfeden yazar, çıplaklık ve giyinme diyalektiğini etik bağlamında bir zemine oturtmaya çalışır. Bu noktada ise metaforik anlamda "giyinme" kavramı özelinde fazilet, yalnızca görsel anlamda "şık" olmakla özdeşleştirilir. Dolayısıyla giyinme, görüneni örtme/gizleme düşüncesine indirgenirken, önemli olanın bu gizleme biçimini dış dünyaya estetik görünecek biçimde yapmak olduğuna işaret edilir: "Çılakları giydirmek! Ben giyinmesini bilmiyorum. Bu dünyada fazilet bir zarafetten ibarettir. Elegansı mubafaza etsinler, kâfi." (Safa 2016: 167).

Böylesi bir indirgeme durumu, meselenin felsefi yönünün derinliğini anlamak açısından önem arz etmektedir. Modern dünya kendi kurallarının izin verdiği ölçüde ve kendi estetik anlayışı doğrultusunda bir "giyinme" biçimi sunar. $\mathrm{Bu}$ giyinişin tek önemli ölçütü kurallara uygunluk sağlamasıdır. "Çıplaklık”la ortaya çıkan anarşi durumunun, kurallara uygun bir şekilde giyinilerek yok edilmesi/giderilmesi amaçlanmaktadır. Burada işaret edilen "elegans” kavra$\mathrm{m} 1$ ise yine belirli bir zümrenin giyim kuşam zevkleri dahilinde ortaya çıkan bir anlayıştır. Şahsi zevkler, toplumun önde gelen isimlerinin/zümrelerinin 
oluşturduğu zevklerle uygunluğu ölçüsünde kabul görebilir yahut da görmez. $\mathrm{Bu}$ ayrilık hâli, biz ve ötekiler düşüncesi çerçevesinde bir ikiliği doğurur ve beraberinde yabancılaşmayı getirir.

"Çıplaklık" durumuna geçilmesi olarak tanımlayabileceğimiz "soyunma" hâli ise insanın kendinden ödün vermesi ile özdeşleştirilmiştir. Çünkü anlatılan hikâyenin peşinden giden Muharrir, kendilik durumundan çıkarak, kendi özünden uzaklaşıp hikâyenin ve onu kaleme alan yazarın hayal dünyasının bir parçası haline gelir.

"Ve ben inanyorum, ona kendimi veriyorum, teslim oluyorum, ben ki her seyden şüphe ederim, onun hiçbir sözünden şüphe etmiyorum, hayatının mubayyel romanin bir hatıra defteri sanıyorum, bir roman kabramanı gibi kendi kendisinden çıkardiğ yeni büviyetini hakikat gibi kabul ediyorum, beraber oluyorum, pesinden gidiyorum, o giyiniyor, ben soyunuyorum." (Safa 2016:134)

Vildan karakteriyle somutlaşan modern insan prototipinin durumu "asrın hastalığı” olarak nitelendirilmiş ve bu buhranlı ruh hâlinin sonuna gelindiğine işaret edilmiştir. En azından anlatıcının düşüncesi bu şekildedir.

"Paris'ten buraya, dostlarımdan biriyle evlenmek için, Amerikalı bir kadın gelmişti. Hep: "Kendi kendimden kaçmak istiyorum, kendime ve hiçbir șeye tahammül edemiyorum, dolașmak, diyardan diyara gitmek... Başka tesellim kalmadı, boğuluyorum!" diyordu. Burada da oturamadı ve dostumla nişanlı olduğu halde kalkıp gitti. "Asrın hastalığg" dedikleri bu ruh bubrane, bu süphe ve tereddüt, bu yer değģştirme ve kaçma ibtiyacı artık sonuna geliyor. Bunu bissediyoruz. Şu uyuyan kadin ve bütün ona benzeyenler, son kurbanlar. Vakıâ insan ruhunun azabı ebedîdir; fakat bu azap mahiyetini değistirmek üzeredir"(Safa 2016: 193).

Yazarın Vildan karakterinin özellikleri ile somutlaştırdığı insan tipi üzerinden "çıplaklık" kavramına ilişkin düşünsel sorgulamalarının son tahlilde yergiye dönüşmesi ve Vildan'ın zayıf bir karakter olarak gösterilmesi, anlatıcının kendi içerisinde bir çeşit ikilemde olduğuna işaret eder. Bu durum, modernizm ile birlikte yaşamın her yanına yayılan diyalektik düşünceler ve ilişkiler sisteminin bir yazarın düşünce dünyasına sızması olarak değerlendirilebilir. 


\section{SONUÇ}

Bu çalışmada Peyami Safa'nın "Bir Tereddüdün Romanı" adlı eserinde yer alan "çıplaklık" kavramı ele alınmış ve kavram, sağladığı imkân dahilinde modernizme ait kavram ve düşünceler ekseninde yorumlanmıştır. Modern insan tipinin çizdiği sınırlara bir tepki olarak düşünebileceğimiz "çıplaklık" kavramı hem ruhsal hem de bedensel anlamda alışılmışın dışına çıkma durumu ile özdeşleştirilmiştir. Bu özdeşlik, eserden yapılan alıntılar bağlamında incelenerek yorumlanmış ve özellikle modern bireyin "çıplaklık" kavramı bağlamında oturduğu eksen tartışılmıştır. Peyami Safa'nın kendi bakış açısının eserle olan bağlantısı üzerinden "çıplaklık" ve "giyinme" kavramlarının iki zıt kavram olmasına rağmen birlikte kullanılmasının nedenleri üzerine düşünülmüş, eserin kahramanlarının dış dünya ve kendi benlikleriyle kurdukları ilişkilere odaklanılmıştır. Sonuç olarak, kurgusal düzlemde metnin oluşmasını sağlayan Muharrir karakterinin modern insana ait sancılar içerisinde olduğu, özellikle kendi karakterine yakın bir tip olarak ortaya çıkan Vildan ile birlikte açığa çıktığı görülmüştür. Vildan ve Muharrir'in iki ayrı çevrede yetişmiş iki ayrı insan olmalarına rağmen hayata bakış açıları ve onu alımlama biçimlerinin "Çıplakları Giydirmek" adlı eserin diyalektik çağrışımları bağlamında özdeş olduğu görülmüştür. Her iki karakterin de bakış açılarının farklılığı nedeniyle söylemlerine yansıyan farklı düşüncelerin anlatıcının bakış açısı doğrultusunda oturduğu zemin tartı̧̧ılmıştır. 


\section{KAYNAKLAR}

Adorno, Theodor W., Max Horkheimer (2010). Aydinlanmanın Diyalektiği, Çev. Nihat Ülner, Elif Öztarhan Karadoğan, İstanbul: Kabalcı Yayıncılık.

Berman, Marshall (2013). Katı Olan Her Şey Buharlaşıyor, Çev. Ümit Altuğ, Bülent Peker, İstanbul: İletişim Yayınları.

Calinescu, Matei (2017). Modernliğin Bę̧ Yüzü, Çev. Sabri Gürses, İstanbul: Küre Yayınları.

Enginün, İnci (2017). Cumburiyet Devri Türk Edebiyat, İstanbul: Dergah Yayınları.

Foucault, M. (2015). İktidarın Gözü, (Çeviren: Işık Ergüden), İstanbul: Ayrıntı Yayınları.

Habermas, J. (1996). Modernity: An Unfinished Project. Habermas and the Unfinished Project of Modernity: Critical Essays on the Philosophical Discourse of Modernity (Der. M.P. d'Entreves ve S. Benhabib) içinde, Polity Press, Cambridge.

Nietzsche, F. (2017). Putların Alacakaranlığı (5. Baskı), (Çeviren: Mustafa Tüzel). İstanbul: İş Bankası Kültür Yayınları s.7.

Safa, Peyami (2016). Bir Tereddüdün Roman1, İstanbul: Ötüken Neşriyat.

Taylor, Charles (2017). Modernliğin Sıkıntıları, Çev. Uğur Canbilen, İstanbul: Ayrıntı Yayınları.

Touraine, Alain (2016). Modernliğin Eleştirisi, Çev. Hülya Uygur Tanrı̈ver, İstanbul: Yap1 Kredi Yayınları.

Woolf, Virginia (1934). “Mr. Bennett and Mrs. Brown” Collected Essays, Ed. Leonard Woolf, Vol. 1 London: Hogarth, 1924, ss. 1-24. 